\title{
The EU's strategic projection in the Indo-Pacific
}

\author{
La proyección estratégica de la UE en el Indo-Pacífico
}

\author{
Juan Luis López-Aranguren \\ University of Zaragoza \\ jlopezar@unizar.es
}

Summary: I. Introduction.-II. Emergence and evolution of the Indo-Pacific concept. - III. The incentives for a European strategy on Indo-Pacific.-IV. The development of national and European strategies for Indo-Pacific. IV.I. The importance of security in the French approach. IV.II. The multilateralism in the German projection to Indo-Pacific. IV.III. The economic dimension and Netherlands. IV.IV. The EU's geopolitical strategy for the Indo-Pacific.-V. Conclusions.

\begin{abstract}
The Indo-Pacific is becoming the new geopolitical axis of the planet for multiple reasons, among which three stand out: security (with six nuclear powers in the area, some of them amidst clearly growing tensions), demography (with 64 percent of the world population) and economy (with 62 percent of world GDP). Since its founding, the European Union has been absent in the development of a strategy for the region, an absence that has recently ended with the publication of national strategies of three member states (France, Germany, and the Netherlands), as well such as the EU announcement of a future EU strategy for the region. This paradigm shift may mark the beginning not only of greater European cohesion in terms of strategic projection, but also of greater European geopolitical assertiveness in a post-COVID-19 world in the Indo-Pacific and other regions. This article will trace the birth and evolution of the Indo-Pacific concept, will identify the reasons for its geostrategic importance for the European Union, and will analyze both the three national strategies of France, Germany, and the Netherlands as well as the announced EU strategy for the region.
\end{abstract}

Keywords: Indo-Pacific, Europe, geopolitics, security, Free and Open IndoPacific (FOIP).

Resumen: El Indo-Pacífico se está convirtiendo en el nuevo eje geopolítico del planeta por múltiples razones entre las que destacan tres: seguridad (con seis potencias nucleares en la zona, algunas de ellas entre claras tensiones crecientes), demografía (con el 64 por ciento de la población mundial) y economía (con el 62 por ciento del PIB mundial). Desde su fundación, la Unión Europea ha estado 
ausente en el desarrollo de una estrategia para la región, una ausencia a la que se ha puesto fin recientemente con la publicación de estrategias nacionales de tres estados miembros (Francia, Alemania y Países Bajos), así como el anuncio de la UE de una futura estrategia comunitaria para la región. Este cambio de paradigma puede marcar el inicio no solamente de una mayor cohesión europea en materia de proyección estratégica, sino también de una mayor asertividad geopolítica europea en un mundo post-COVID-19. En este artículo se rastreará el nacimiento y la evolución del concepto del Indo-Pacífico, se identificarán las razones de su importancia geoestratégicas para la Unión Europea y se analizarán tanto las tres estrategias nacionales de Francia, Alemania y the Netherlands como la anunciada estrategia de la UE para la región.

Palabras clave: Indo-Pacífico, Europa, geopolítica, seguridad, Estrategia del Indo-Pacífico Libre y Abierto (FOIP). 


\section{Introduction}

The Indo-Pacific has emerged in the 21 st century as one of the geopolitical centers that will most powerfully determine the future of world politics. This may have been accelerated by the impact of COVID-19, which has temporarily interrupted the global supply chain, passenger transport, and globalizing forces that pointed to an increasingly globalized economy ${ }^{1}$. This has led to a decrease in trade dependence on China, pushing the Western powers to devote greater attention to national production capacities and the importance of their predominance in black swanlike scenarios such as this one. This may have enhanced in Europe the need to have its own geopolitical strategy for Asia and the Indo-Pacific. This situation creates an incentive for Western powers, especially European nations, to adopt a greater geopolitical assertiveness in this new global axis. This led three European nations (France, Germany, and the Netherlands) to develop their own strategies for the region and the publication by the European Union of a draft document with the general lines of a future community strategy for this area. This article will analyze the evolution of the Indo-Pacific concept, its geostrategic importance for Europe, the different initiatives offered to date, and the possible future evolution of this European geopolitical projection in the region, as well as its impact on the world.

\section{Emergence and evolution of the Indo-Pacific concept}

The concept of the Indo-Pacific has evolved from the initial concept of Asia and, later, that of the Asia-Pacific. Asia, as a geopolitical term, responds to a purely geographical concept centered on China, a continental idea devoid of multilateral connotations on the political plane. This concept gave rise in the 1980s to the concept of Asia-Pacific, which was no longer a purely geographical term and incorporated an economic dimension. Likewise, the continental slope incorporated the maritime one and acquired multilateral connotations with the creation of the Asia-Pacific Economic Cooperation (APEC) Forum in 1989, although it excluded India. Finally, in the first decade of the 21 st century, this concept evolved to that of the Indo-

1 Juan Luis López-Aranguren, "Japón y la pandemia del COVID. Análisis comparativo entre Japón y España de la dimensión comunicativa en la lucha contra el COVID-19”, en R. Vilarroig (Ed.), Derecho, Empresa y Administración pública en Japón. Con referencia al tratamiento de la pandemia de la COVID-19 en Japón (Madrid: Tirant lo Blanch, 2021), 255276. 
Pacific, transforming its original meaning. To the economic dimension of Asia-Pacific, the security dimension was added, and the term became a maritime concept when describing all the nations bathed by these two oceans and marked the birth of the articulation of a new geopolitical axis of the planet. India was included in this concept and its formal crystallization was born with the Quadrilateral Security Dialogue (QUAD) between Japan, the US, Australia, and India.

However, even though the modern use of the Indo-Pacific as a geopolitical concept began in the $21^{\text {st }}$ century, it is possible to trace the first references to this region at the end of the 19th century. It is in this period when the American naval historian and strategist Alfred Thayer Mahan predicted, "whoever dominates the Indian Ocean will dominate Asia and the fate of the world will be decided in its waters" 2 . In 1924, the German geographer and politician Karl Haushofer predicted the arrival of what he called "the Pacific Age" 3 . In the 1980s, during the legendary meeting between Deng Xiaoping and Indian Prime Minister Rajiv Gandhi, came the declaration by Deng Xiaoping indicating that only when China, India, and other neighboring nations cooperate, one could speak of a "century of AsiaPacific" 4 . In the $21^{\text {st }}$ century, in 2009, the US Secretary of State Henry Kissinger stated, "one of the most drastic global changes that would take place in this century would be the shift of the center of gravity of international relations from the Atlantic to the Indian Ocean and Pacific"5. We can find a common trend here: the seas and oceans are the vectors that allow powers to expand and project their hard or soft power beyond the limitations of their territorial scope. For example, the Mediterranean was not only the bridge of communication and trade of classic civilizations like Greece, Rome, and Phoenicians, but also a space for diplomatic competition and struggle for resources, influence, and expansion of colonies, as described by Thucydides in his Peloponnese War.

Similarly, the Atlantic Ocean was also the battlefield of a strategic competition projected overseas since the $15^{\text {th }}$ century by the whales (maritime European powers, in contrast with the elephants or land powers) towards America and West Africa. British geographer scholar Ian

2 David Brewster, “An Indian Sphere of Influence in the Indian Ocean?", Security Challenges, Spring 2010, 6(3): 1-20. p. 2.

${ }^{3}$ Karl Haushofer, Geopolitik des pazifischen ozeans (Berlin: Vowinckel, 1924).

${ }^{4}$ Deng Xiaoping, Deng Xiaoping Wenxuan (Selected Works of Deng Xiaoping), Vol. 3 (Beijing: Renmin chubanshe (People's Publishing House), 1993), 281.

5 Atlantic Council. 2009. "Transcript: Kissinger's Remarks at 2009 Makins Lecture”, January 15, 2009, https://www .atlanticcouncil.org/commentary/transcript/transcript-kissinger-s-remarks-at-2009-makins-lecture/, Accessed August 1, 2021. 
Morris $^{6}$ explained that the geopolitical possibilities of nations reach their maximum scope in the sea: the reason why Europe had become a global power since the 15th century and expanded its civilization throughout the planet was that Europe was a peninsula of peninsulas, and it offered easy access to the sea for any idea, product, military force and revolution that wanted to be exported and imported. The sea has been, hence, an accelerator of social evolution in those civilizations that had the strategic advantage of easy access to it. For this reason, the approach to the future evolution of global dynamics from a maritime perspective rather than a land-based one may be more practical when defining possible future scenarios ${ }^{7}$. Therefore, perhaps it is more appropriate to speak of an IndoPacific era rather than a continental Asian century ${ }^{8}$.

\section{The incentives for a European strategy on Indo-Pacific}

Three dimensions can make the Indo-Pacific become a global axis for the planet and, therefore, Europe has strong incentives to develop its own strategy for the region: security, economic, and demographic.

This region connects the three main economies of the planet (USA, China, and Japan). Together they represent more than 45 percent of world GDP. The fifth-largest economy in the world, India, also participates in this region with a potential for future growth capable of multiplying its size by 2.5 times in the next decade. In addition, there is a deep dependence among these economies that have continued to increase in recent years, interrupted only temporarily by the COVID-19 disruption of the global supply chain networks.

Encompassing all the Indo-Pacific nations, this region involves 38 countries, 44 percent of the world surface, 65 percent of the planet's population (including the two most populated nations on the planet, India and China, with more than 2800 million people in the group) and 62 percent of world GDP ${ }^{9}$. These statistics can help us put in perspective the real weight

${ }^{6}$ Ian Morris, Why the West Rules-For Now: The Patterns of History, and What They Reveal About the Future (New York: Farrar, Straus and Giroux, 2010).

7 Juan Luis López-Aranguren, "Las dimensiones geopolítica y comunicativa de la disputa por las islas Senkaku/Diaoyu a través de la historia", in Carmen Tirado (Ed.), El agua en Japón. Una aproximación jurídica y social (Valencia: Tirant lo Blanch, 2018: 205-250).

8 Juan Luis López-Aranguren. "El Indo-Pacífico como nuevo eje geopolítico global", Global Affairs 3 (2021): 6-11. https://www.unav.edu/documents/16800098/0/Global+Affairs +Journal+3rd+Edition.pdf

9 Rahman, Mohamad Masudur Rahman, Chanwahn Kim \& Prabir De, "Indo-Pacific cooperation: what do trade simulations indicate?", Economic Structures 9(45) (2020): 2. https://doi.org/10.1186/s40008-020-00222-4 
the region has on the dynamics of international relations and that its importance will continue to increase due to unavoidable demographic and economic factors.

Moreover, in terms of the geopolitical dimension, the Indo-Pacific, in its widest geographical expanse, encompasses five recognized nuclear powers: the US, Russia, China, India, and Pakistan. North Korea should be added to this list, except for operational doubts raised about its nuclear program. All the three generations of nuclear powers (original post-World War II states, the new regional powers in the $90 \mathrm{~s}$, and rogue states of the millennium) are present in this scenario.

This enormous diversity of nuclear-capable actors, each with a very different sphere of influence and political objectives, greatly increases the complexity of interactions in this region of the planet and raises the cost of any friction between them. In June 2020, twenty Indian soldiers died in a confrontation with Chinese troops in Ladakh, on the disputed border between these two nations ${ }^{10}$. In November of the same year, five soldiers and ten civilians were killed in clashes between Indian and Pakistani troops ${ }^{11}$. In addition, in December, Pakistan and China began joint Shaheen ("Eagle") IX military air exercises in Sindh province, intensifying pressure on India ${ }^{12}$.

In the same way as the rest of the actors in the region, India has been compelled to adopt a more assertive attitude given the escalation of tensions in the area. This has included the launch of the informal strategic collaboration project between India, Japan, the USA, and Australia called the Quadrilateral Security Dialogue or simply QUAD ${ }^{13}$. This initiative, which has been described as "Asian NATO"14, was launched in 2007 but only had a few months of running in its first attempt before being paralyzed by three main factors ${ }^{15}$. First, China held the Beijing Olympic Games and

10 Aman Dwivedi. "Highlights: 20 Indian Soldiers Killed; 43 Chinese Casualties In Ladakh", NDT, June 17, 2020, https://www.ndtv.com/india-news/india-china-updates-army-officer2-soldiers-killed-in-violent-face-off-with-china-in-ladakh-2247070, Accessed August 1, 2021.

11 Al Jazeera, "India, Pakistan report deadly violence along Kashmir border", 2020, November 13, https://www.aljazeera.com/news/2020/11/13/pakistan-summons-top-indian-diplomat-over-kashmir-violence

12 Ananth Krishnan, "China tells India to look at Pakistan military exercises 'objectively", The Hindu, 2020, December 21, https://www.thehindu.com/news/international/takean-objective-view-on-chinese-pakistan-air-force-drills-china-tells-india/article33385259.ece

13 Tavin Madan, "The Rise, Fall, and Rebirth of the 'Quad"”, War on the rocks, 2017, November 16, https://warontherocks.com/2017/11/rise-fall-rebirth-quad/

${ }^{14}$ Brahma Chellaney, The Quad: Asia's Own NATO?, The ASEAN Post, 2020, October 19, https://theaseanpost.com/article/quad-asias-own-nato

15 Rachel Zhang, "Could a US-led Quad add up to an Asian Nato against China?", South China Morning Post, 2020, December 25, https://www.scmp.com/news/china/diplomacy/article/3115262/could-us-led-quad-add-asian-nato-against-china, Accessed August 1, 2021. 
maximized its international projection through soft power ${ }^{16}$ and public diplomacy ${ }^{17}$. Second, at the end of 2007, the coming to power of Yasuo Fukuda, Prime Minister of Japan, replacing Shinzo Abe, implied the beginning of a diplomatic rapprochement with Beijing and the adoption of more conciliatory measures during his brief mandate that barely lasted a few months ${ }^{18}$. Third, Indian Prime Minister Manmohan Singh joined in this trend and, on a visit to China in January 2008, declared that India-China relations were a priority ${ }^{19}$. Most importantly, the QUAD did not take off because Australia was very wary of displeasing Beijing and withdrew from it.

However, the collaboration between the four QUAD nations continued in other formats, including in 2012 with the deployment of US Marines to Darwin, near the Lombok Strait ${ }^{20}$, and most importantly, the Malabar naval military exercises, which originally began as a bilateral US-India collaboration in $1992^{21}$. The 2020 edition of the Malabar exercises saw the participation of Australia, which has meant that it has been the first time in 13 years that all members of the QUAD group have participated in these military maneuvers together ${ }^{22}$.

This security dimension of the QUAD led Japan to launch the idea of the Free and Open Indo-Pacific (FOIP) Strategy in 2016. Japan changed the usage of the term "strategy" into "vision" in 2018. This concept had initially germinated in the margins of Japanese and American political

16 Japan, one of the members of the Quad group, has also maximized its global communicative projection employing the so-called Olympic diplomacy. Juan Luis López-Aranguren, "La diplomacia olímpica de Japón: De Tokio 1964 a Tokio 2021", Mirai. Estudios Japoneses 5, 2021, 67-76. Doi: https://dx.doi.org/10.5209/mira.74697

$17 \mathrm{Yu}$ Wai Li, "Public Diplomacy Strategies of the 2008 Beijing Olympics and the 2012 London Olympics: A Comparative Study", The International Journal of the History of Sport 30(15) London 2012: Prism for East Asian Political Preoccupations, 2013:1723-1734. https://doi.org/10.1080/09523367.2013.790374

${ }_{18}$ Ministry of Foreign Affairs (MOFA), Japan, "Forging the Future Together. Speech by H.E. Mr. Yasuo Fukuda, Prime Minister of Japan at Peking University, Beijing, People's Republic of China", 2007, December 28, https://www.mofa.go.jp/region/asia-paci/china/ speech0712.html

${ }^{19}$ Ministry of External Affairs (MEA), India, "Visit of Prime Minister Dr. Manmohan Singh to China", January 13-15, 2008", 2008, January 13-15 https://mea.gov.in/outgoing-visit-info. htm?2/105/Visit+of+Prime+Minister+Dr+Manmohan+Singh+to+China+January+1315+2008

${ }^{20}$ Matt Siegel, "As Part of Pact, U.S. Marines Arrive in Australia, in China's Strategic Backyard", The New York Times, 2012, April 4, https:/www.nytimes.com/2012/04/05/world/ asia/us-marines-arrive-darwin-australia.html

${ }^{21}$ Gurpreet S. Khurana, "Joint Naval Exercises: A Post-Malabar-2007 Appraisal for India", Institute of Peace and Conflict Studies 52, 2007, September 1.

22 Indian Navy, "Phase 2 of Exercise Malabar 2020 in Western Indian Ocean", 2020, https://www.indiannavy.nic.in/content/phase-2-exercise-malabar-2020-western-indian-ocean, Accessed August 1, 2021. 
spheres, each with different nuances and interpretations until it impregnated much of the communicative and diplomatic interactions of both nations ${ }^{23}$ in the region ${ }^{24}$. The US State Department formalized the concept in $2019^{25}$ and since then, it has become popular worldwide, influencing other nations to incorporate the concept in their strategic policies ${ }^{26}$.

This Indo-Pacific initiative is part of Japan's need to encourage its assertiveness in security matters, a need that has also generated proposals to reform its intelligence services ${ }^{27}$, improve the intelligence sharing with South $\mathrm{Korea}^{28}$, adapt its legislation to its external security needs ${ }^{29}$, and face new threats like terrorism ${ }^{30}$.

The two key strategies of the FOIP are reflected in the term itself, indicating the intention to maintain this key region of the world as free and open. This first concept of freedom is understood in two different ways. In the first place, as the American security adviser Herbert R. McMaster explained, "freedom of navigation, overflight, rule of law, sovereignty, freedom from coercion and freedom of business and market" 31 . This could also be taken to understand freedom as democratic nations. Indistinctly, one and the other interpretation are closely related.

23 Abhijit Singh, “The Nautical Dimension of India's "Act East” Policy”, S. Rajaratnam School of International Studies (RSIS), 2018, April 1.

${ }^{24}$ Emma Chanlett-Avery, "Japan, the Indo-Pacific, and the "Quad", Chicago Council of Global Affairs, 2018, February 1.

25 Department of State, United States. A Free and Open Indo-Pacific. Advancing a Shared Vision, 2019, November 4, https://www .state.gov/wp-content/uploads/2019/11/Free-andOpen-Indo-Pacific-4Nov2019.pdf, Accessed August 1, 2021.

${ }^{26}$ Wada Haruko, "The "Indo-Pacific" Concept: Geographical Adjustments and their Implications”, RSIS Working Paper 326, S. Rajaratnam School of International Studies (RSIS), 2020, March 16.

27 Juan Luis López-Aranguren, "The Communicative Dimension and Security in AsiaPacific: A communicative-viewing proposal for reform of the Japanese Intelligence Services”, UNISCI Discussion Papers 41, 2016: 29-52. doi:10.5209/rev_RUNI.2016.n41.52673

28 Juan Luis López-Aranguren, "Seoul and Tokyo's new security axis: If you want peace... share intelligence", Asia and The Pacific Policy Society Forum, December 9, 2017. https://www.policyforum.net/seoul-tokyos-new-security-axis/, Accessed on: August 1, 2021.

${ }^{29}$ Carmen Tirado, "Las recientes reformas legislativas en materia de política exterior y seguridad en Japón”, Política exterior de Japón 3, 2019: 69-86.

30 Juan Luis López-Aranguren, "Gas sarín, sectas y propaganda en Japón: El conflicto entre libertad de expresión, religión y seguridad a raíz de los ataques de Aum Shinrikyō”, in

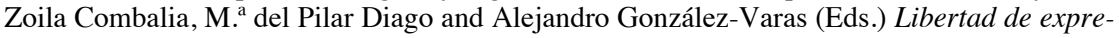
sión y discurso de odio por motivos religiosos, Zaragoza: LICREGDI, 2019: 149-219, https:// dialnet.unirioja.es/descarga/libro/744767.pdf

31 James Laurenceson, Freedom and openness in the Asia Pacific free and open for interpretation, East Asia Forum, 2017, November 14, https://www.eastasiaforum.org/2017/11/14/ freedom-and-openness-in-the-asia-pacific-free-and-open-for-interpretation/, Accessed August $1,2021$. 
The second concept of openness could also be interpreted in two different ways. In the first place, as an Indo-Pacific open to all the nations of the globe, without excluding anyone from its use or participation in the institutional construction of its political architecture. Second, as an IndoPacific open to expansion to new dimensions beyond just security and the economy, and inclusive of education, development, culture, environmental protection $^{32}$, public health, and communication ${ }^{33}$ (a dimension in which Japan $^{34}$ is considered a global superpower) leading to the enhancement of its competitiveness and innovation ${ }^{35}$ maintaining its cultural identity ${ }^{36}$.

This Free and Open Indo-Pacific (FOIP) strategy, however, is still in a very early phase of the definition and each nation interprets it in its own way. As mentioned before, Japan ${ }^{37}$ changed its stance and began to describe the FOIP as a vision and not a strategy in 2018. This is believed to have been done to accommodate the concerns of the Association of Southeast Asian Nations (ASEAN) who did not want to choose between the US and China $^{38}$. The change also coincided with a period of warming of relations between China and Japan ${ }^{39}$. The US, for its part, displayed an erratic foreign policy during the Trump administration in which the start of a trade war with

32 The environmental protection is one of the top contributions of Europe to international law. Steffen Bay Rasmussen, "Presentation", Cuadernos Europeos De Deusto 64. A sustainable Europe: Society, Politics and Culture in the Anthropocene, May 2021: 19-22. https://doi. org/10.18543/ced-64-2021pp19-22

33 Juan Luis López-Aranguren, "Rational Choice Theory and International Communication: A Proposal for a New Interpretation of Article 21 of the Japanese Constitution", Osaka University Law Review 64 (2017):111-134. https://ir.library.osaka-u.ac.jp/repo/ouka/ al1/59680/oulr064-111.pdf

34 Juan Luis López-Aranguren, "De los panfletos de mayo de 1968 a los foros digitales del siglo XXI: Oportunidades y desafíos de la comunicación internacional en la articulación global de los movimientos sociales", in E. Postigo (Coord.), Mayo del 68. Una época de cambios, un cambio de época, Vol. II (Madrid: Editorial Universidad Francisco de Vitoria, 2019), 13-22.

35 Juan Luis López-Aranguren, "El glocalismo como herramienta para potenciar la creatividad y la innovación de Japón en un mundo globalizado", MIRAI. Estudios Japoneses 4 (2020): 11-22. http://dx.doi.org/10.5209/mira.67540

36 Juan Luis López-Aranguren, "Del Tatte Shakai a las particularidades culturales y comunicativas de la sociedad nipona: desafíos de la investigación en CCSS en Japón", in Carmen Tirado and Francisco Barberan (Eds.), Derecho y relaciones internacionales en Japón: Desde el Tratado de Amistad, Comercio y Navegación de 1868 (Zaragoza: Prensas de la Universidad de Zaragoza, 2019), 273-304.

${ }^{37}$ Ministry of Foreign Affairs (MOFA), Japan, "What is Free and Open Indo-Pacific?", 2021, February 1, https://www.mofa.go.jp/policy/page25e_000278.html., Accessed on: August 1, 2021.

38 Celine Pajon, "Japan's Indo-Pacific Strategy: Shaping a Hybrid Regional Order", 2019. December 18, https://warontherocks.com/2019/12/japans-indo-pacific-strategy-shaping-a-hybrid-regional-order/

39 Yoshihide Soeya, "Japan and the Indo-Pacific: from strategy to vision", ASPI, 2020, January 22, https://www.aspistrategist.org .au/japan-and-the-indo-pacific-from-strategy-to-vision/ 
China ${ }^{40}$ was combined with speculation of a possible withdrawal of US troops from Okinawa ${ }^{41}$. This would have left Japan in a very delicate position since Article 9 of its Constitution ${ }^{42}$ that denies the right to war and the possession of armed forces has not been modified (something that has been determined by both Japan's foreign policy and its internal political dynamics $)^{43}$. It is true that in 2014 a new and revolutionary constitutional interpretation of this article was made, expanding Japan's room for maneuver in defending its territorial integrity and autonomy ${ }^{44}$. However, the erratic announcements regarding collective security with the United States introduce a very high uncertainty factor, even if it was meant merely as a domestic political stunt aimed at taxpayers. This situation is aggravated due to the escalation of frictions with China over the Senkaku / Diaoyu islands ${ }^{45}$.

Australia, for its part, has been reluctant longer than its allies to adopt a position that could provoke China, which has consequently delayed its full participation in these activities. However, as described above, its recent return to the Malabar Naval Exercises in 2020 marks a change in the Australian approach reflecting a move to a more assertive stance.

India, the country with the largest continental territorial dispute with China and the only country that has had a war with China in the second half of the twentieth century, has been found paradoxically limited in its power projection in the Indo-Pacific due to the need to concentrate resources on responding to continental threats ${ }^{46}$. Indian Prime Minister Narendra Modi,

40 BBC, “A quick guide to the US-China trade war", 2020, January 16, https://www.bbc. com/news/business-45899310, Accessed August 1, 2021.

41 Bloomberg, "Trump Muses Privately About Ending Postwar Japan Defense Pact", 2019, June 25, https://www.bloomberg.com/news/articles/2019-06-25/trump-muses-privately-about-ending-postwar-japan-defense-pact, Accessed August 1, 2021.

${ }^{42}$ Prime Minister of Japan and His Cabinet, Japan, The Constitution of Japan. 1946, https://japan.kantei.go.jp/constitution_and_government_of_japan/constitution_e.html, Accessed August 1, 2021.

43 Juan Luis López-Aranguren, "De los panfletos de mayo de 1968 a los foros digitales del siglo XXI: Oportunidades y desafíos de la comunicación internacional en la articulación global de los movimientos sociales", en E. Postigo (Coord.), Mayo del 68. Una época de cambios, un cambio de época, Vol. II (Madrid: Editorial Universidad Francisco de Vitoria, 2019), 13-22.

${ }^{44}$ Linda Sieg, L \& Kiyoshi Takenaka, "Japan takes historic step from post-war pacifism, OKs fighting for allies”, Reuters, 2014, July 1, https://www.reuters.com/article/us-japan-defense-idUSKBNOF52S120140701, Accessed August 1, 2021.

45 Juan Luis López-Aranguren, "Las dimensiones geopolítica y comunicativa de la disputa por las islas Senkaku/Diaoyu a través de la historia", in Carmen Tirado (Ed.), El agua en Japón. Una aproximación jurídica y social (Valencia: Tirant lo Blanch, 2018), 205-250.

46 Arzan Tarapore, "The Army in Indian Military Strategy: Rethink Doctrine or Risk Irrelevance”, Carnegie India, 2020, August 10, https://carnegieindia.org/2020/08/10/ army-in-indian-military-strategy-rethink-doctrine-or-risk-irrelevance-pub-82426, Accessed August $1,2021$. 
who has been compared to Shinzo Abe in his views on this region, has been trying ${ }^{47}$ to change this ${ }^{48}$, although other analysts have highlighted the important differences ${ }^{49}$ between the two ${ }^{50}$. Modi's strategy is not, in any case, an easy path: there are numerous internal and external risks and obstacles when it comes to adopting a more assertive attitude. Among them, we can highlight the serious internal economic and development challenges that India has to face, which may pose a serious risk of instability if it embarks on an external military escalation ${ }^{51}$.

The Indo-Pacific future depends, therefore, on a large number of both domestic and international variables that are changing constantly and that should be analyzed carefully by policymakers. Therefore, it is not surprising that the first steps of this new collaboration of the Free and Open Indo-Pacific Strategy have been centered on projects creating infrastructure and support for development. For example, the construction of subway systems in many Indian cities like Delhi, Mumbai, and Chennai by Japanese companies and with French participation ${ }^{52}$, which reinforces EUJapan cooperation ${ }^{53}$ and generates a big incentive for the European Union to acknowledge the challenges in the security dimension if the EU wants to

47 Malini Goyal, M. \& Dipanjan Roy Chaudhury, "Will economic empathy shared by Narendra Modi and Shinzo Abe enable Japan to play key role in India's growth?", The Economic Times, 2014, June 1, https://economictimes.indiatimes.com/news/economy/indicators/ will-economic-empathy-shared-by-narendra-modi-and-shinzo-abe-enable-japan-to-play-keyrole-in-indias-growth/articleshow/35852162, Accessed August 1, 2021.

48 Nyshka Chandran, “There's more to Modi-Abe ties than China”, CNBC, 2014, September 2, https://www.cnbc.com/2014/09/02/why-the-modi-abe-bromance-isnt-just-aboutchina.html, Accessed August 1, 2021.

49 Dhara Ranasinghe, "Why Abenomics and Modinomics are poles apart", CNBC, 2014, June 25, https://www.cnbc.com/2014/06/25/why-abenomics-and-modinomics-are-polesapart.html

50 Jeffrey W. Hornung, \& Shyam Tekwany, "Modi is NOT India's Shinzo Abe”, The Diplomat, https://thediplomat.com/2014/05/modi-is-not-indias-shinzo-abe/, 2014, May 27, Accessed August 1, 2021.

51 Shahana Thankachan, "Japan's Security, Export Control and Arms Export Policy: Prospects for India-Japan Defence Cooperation”, Delhi Policy Group Vol. V(37), 2020, October 17, https://www.delhipolicygroup.org/uploads_dpg/publication_file/japans-security-export-control-and-arms-export-policy-prospects-for-india-japan-defence-cooperation-2085.pdf

52 Medium "Japan and France join India on the country's first high-speed rail connection", 2020, August 1, https://medium.com/tripetta-india/japan-and-france-join-india-on-thecountrys-first-high-speed-rail-connection-4280350f5eb1, Accessed August 1, 2021.

53 Ana Gascón, "Society 5.0: EU-Japanese cooperation and the opportunities and challenges posed by the data economy", ARI 11/2020, Real Instituto Elcano, 2020, February 4, http://www.realinstitutoelcano.org/wps/portal/rielcano_en/contenido?WCM_GLOBAL_ CONTEXT=/elcano/elcano_in/zonas_in/asia-pacific/ari11-2020-gascon-society-5-0-eu-japanese-cooperation-and-opportunities-and-challenges-posed-by-data-economy, Accessed August $1,2021$. 
become a global supporter of global stability ${ }^{54}$. From a diplomatic point of view, this collaboration was highlighted by the Japanese Ambassador to India, Kenji Hiramatsu, as the first step in future Japanese infrastructure development projects in India ${ }^{55}$.

\section{The development of national and European strategies for Indo-Pacific}

Despite the geopolitical importance of the Indo-Pacific, the European Union, as a supranational entity, did not announce a defined strategy for the Indo-Pacific until March 2021. Only three countries (France, Germany, and the Netherlands) have so far produced national official documents in which they develop a strategy on this area. The rest of the members of the European Union do not have any domestic strategy to date.

In this section, we will analyze these four European geopolitical approaches to the Indo-Pacific: the pioneering approach of France, the approach of Germany, and the approach of the Netherlands, and, finally, the announced future geopolitical strategy of the EU for the Indo-Pacific.

\section{IV.I. The importance of security in the French approach}

France has been the pioneer nation in Europe in offering a national approach to the Indo-Pacific, something it did in 2019 by publishing its strategic document entitled "France and Security in the Indo-Pacific" 56 . It should be noted that, due to its overseas departments Mayotte and La Réunion, France is formally an Indo-Pacific nation. This was highlighted in its 2019 document where it indicated that 1.6 million French citizens lived in French overseas departments and territories, 200,000 French Nationals live in the Indo-Pacific states and the region encompassed $465,422 \mathrm{~km}^{2}$ and

${ }^{54}$ Pablo Antonio Fernández Sánchez, "Presentación", Cuadernos Europeos de Deusto 57. La contribución de la Unión Europea a los grandes desafíos de la sociedad internacional, October 2017: 17-25. https://doi.org/10.18543/ced-57-2017pp17-25

55 Business Standard, "Japan's involvement in Delhi Metro underlines close ties with India”, December 3, 2018, Accessed on on: August 1, 2021, https://www.business-standard. com/article/news-ani/japan-s-involvement-in-delhi-metro-underlines-close-ties-with-india-118123100659_1.html,

56 Ministère des Armées, France. France and Security in the Indo-Pacific, 2019, 1, https://www.defense.gouv.fr/layout/set/print/content/download/532754/9176250/version/3/ file/France+and+Security+in+the+Indo-Pacific+-+2019.pdf 
93 percent of its Exclusive Economic Zone ${ }^{57,58}$. In this way, France has become one of the pillars of Europe's geopolitical projection in the Indo-Pacific $^{59}$.

Additionally, in a new strategic move in which it limits China's international projection, France has declared India as its preferred partner in Asia ${ }^{60}$, thus displacing the weight that China could have in this international architecture in general and in the European Union in particular. France's approach focused on security, both in the face of traditional threats and in the face of new climatic threats, natural disasters, etc. This is evidenced by the fact that the institution that has produced this strategic document is the Ministry of Defense ${ }^{61}$. France highlights the importance of the Indo-Pacific for Europe and itself and announces its commitment to this area of the planet with the following words in this strategic document ${ }^{62}$ :

"France pays particular attention to the Indo-Pacific region. Its stability is paramount for international security, as stated in the 2017 Defence and National Security Strategic Review. In the Indo-Pacific area, North Korea challenges the international community by conducting nuclear trials and ballistic missile tests, thereby breaching the resolutions of the United Nations Security Council. The military assertiveness of a growing number of established or emerging powers presents many challenges to multilateralism and increases the instability and unpredictability we are confronted with. Terrorism, which has severely struck Europe over the last few years, is reshaping and spreading to the Indo-Pacific. This worrying evolution requires a joint mobilisation of the international community.

The maritime domain remains an area of tensions due to the challenging behaviour of some States with regards to United Nations Convention on the Law of the Sea and the persistence of acts of piracy. Finally, the effects of climate change and environmental degradations represent a major issue in the Indo-Pacific, and as far as in the Antarctic,

57 Ministère des Armées, France. France and Security in the Indo-Pacific.

58 Ministère de L'Europe et des Affaires Étrangères, France. French Strategy in the Indo-Pacific "For an Inclusive Indo-Pacific", 2019, https://www.diplomatie.gouv.fr/en/ country-files/asia-and-oceania/the-indo-pacific-region-a-priority-for-france/

59 Frederic Grare, "France, the Other Indo-Pacific Power, Carnegie Endowment for International Peace", 2020, October 21, https://carnegieendowment.org/2020/10/21/franceother-indo-pacific-power-pub-83000, Accessed August 1, 2021.

60 The Hindustan Times, "France describes India as foremost Asian strategic partner", 2020, September 9, https://www.hindustantimes.com/india-news/france-describes-india-asforemost-asian-strategic-partner/story-rJmsUIWze24pfh3Ekip7yL.html, Accessed August 1, 2021.

${ }^{61}$ Ministère des Armées, France. France and Security in the Indo-Pacific.

62 Ibidem. 
exacerbating security risks. These major challenges can only be overcome through cooperation.

Upholding stability in the Indo-Pacific, which is a source of overall prosperity thanks to its economic dynamism, demographic growth, and technological innovation, is essential. This has to be set within the framework of an international order based on dialogue and the respect of multilaterally set rules."

The geopolitical importance of this region for France is reflected in the economic data that this document provides ${ }^{63}$. France exported 66.44 billion euros to the Indo-Pacific in 2018, excluding defense equipment, which is equivalent to 34 percent of all exports outside the European Union and 14 percent in total. Similarly, France has imported 95.93 billion euros from the Indo-Pacific (also excluding defense equipment). To protect this area, France has deployed 7,000 military personnel throughout the Indo-Pacific, 2,900 in the Pacific Ocean, and 4,100 in the Indian Ocean. France has divided its military forces into five joint regional commands as follows ${ }^{64}$ : Commander of the French Armed Forces in the South of the Indian Ocean (COMSUP FAZSOI), in New Caledonia (COMSUP FANC), in French Polynesia, and the Pacific Ocean (COMSUP FAPF / ALPACI), in the UAE and the Indian Ocean (FFEAU / ALINDIEN), and in Djibouti (FFDJ), where China opened its first Naval Base overseas in 2017 and it's a vital bottleneck for EU's economy since it allows access to the Red Sea.

Regarding the number of French nationals in overseas departments located in the Indo-Pacific ${ }^{65}$, the document indicates that the most populated region is the one formed by the islands of Mayotte, Réunion, and Scattered Islands, with 1,100,000 inhabitants, followed by New Caledonia (282,000 pop.), French Polynesia (276,000 pop.), and the remaining regions with hardly any permanent population. Similarly, France has nationals in other Indo-Pacific nations: more than 30,000 in China and Australia (each); between 10,000 and 30,000 in Japan, Thailand, India, Bhutan, New Zealand, and Madagascar; between 3,000 and 10,000 in Vietnam, Cambodia, Malaysia, South Korea, the Philippines, Brunei, Indonesia, and East Timor; and less than 3,000 in the remaining countries. France also details the specific security risks in the Indo-Pacific ${ }^{66}$ :

"The 2017 French Strategic Review emphasises the rapid and intense evolution of the threats identified in the 2013 White Paper: terrorism, the

\footnotetext{
63 Ibidem, 2.

${ }^{64}$ Ibidem, 6.

65 Ibidem, 3.

${ }^{66}$ Ibidem, 4.
} 
worrying return of rivalry and power assertiveness, the weakening of the rule of law and multilateralism as well as the increase of unconventional challenges.

North Korea's ballistic and nuclear programs do not only threaten Northeast Asian stability but also the international order and the nonproliferation regime. In the South China Sea, the large-scale land reclamation activities and the militarisation of contested archipelagos have changed the status quo and increased tensions. The potential consequences of this crisis have a global impact considering that one third of the world trade transits through this strategic region. Such a case highlights how multilateralism is questioned by assertive policies which are threatening the stability of the whole region.

Terrorism is another challenge. The end of Daech does not mean the end of this global threat due to Foreign Fighters returning home and the spread of terrorism to new regions such as South Asia and South-East Asia. Scientific and technological breakthroughs are bringing in new opportunities, but also new risks. There is little doubt that accessibility to deep underwater resources, the expansion of power projection and, in parallel, of anti-access / area denial capabilities, and the centrality of cyberspace and satellite equipment, are going to exacerbate rivalries between States in the Indo-Pacific.

Facing those challenges, France is developing a network of strategic partnerships in the Indo-Pacific with countries such as India, Australia, Japan, Malaysia, Singapore, New Zealand, Indonesia and Vietnam. To deal with those risks and tensions, France supports and wishes to contribute to the building of a regional security architecture."

France also collaborates with the regional centers dedicated to the surveillance of maritime spaces and sea-lanes of communication of the IndoPacific. Three French officers contribute to these goals within the Information Fusion Center-Indian Ocean Region (IFC-IOR) located in New Delhi; the Information Fusion Center of Singapore (IFC), and the Regional Center for the Fusion of Maritime Information (CRFIM) located in Madagascar.

Arms cooperation with Indo-Pacific nations also plays a vital role in the role that France plays in the security of this region ${ }^{67}$, India and France, for example, had arms trade worth 13,184 million euros in the period 2008-2017.

\section{IV.II. The multilateralism in the German projection to Indo-Pacific}

The second European country in developing a national strategy for the Indo-Pacific was Germany with a more multi-dimensional approach.

${ }^{67}$ Ibidem, 17. 
Germany published its new policy for the region on September 1, 2020, in a 70-page document titled "Policy guidelines for the Indo-Pacific" 68 . In it, Germany has emphasized the need for multilateralism when addressing the challenges in the Indo-Pacific, while urging North Atlantic Treaty Organization (NATO) to expand its agreements with Japan and South Korea. Likewise, it highlighted the need to support rules and not powers when defining the dynamics of this area, issuing a veiled warning to the Chinese negotiating strategy of relying on bilateralism for the expansion of its global influence ${ }^{69}$. This view has been condensed in the statements of the German Foreign Minister Heiko Maas stating,

"Our prosperity and our geopolitical influence in the coming decades will depend on how we work together with the countries of the IndoPacific region. That, more than anywhere else, is where the shape of the international rules-based order of tomorrow will be decided. We want to help shape that order - so that it is based on rules and international cooperation, not on the law of the strong" 70 .

Germany's strategy is based on seven pillars ${ }^{71}:$ 1) Strengthening multilateralism; 2) Tackling climate change and protecting the environment; 3) Strengthening peace, security, and stability; 4) Promoting human rights and the rule of law; 5) Strengthening rules-based, fair and sustainable free trade; 6) Rules-based networking and the digital transformation of regions and markets; 7) Bringing people together through culture, education, and science.

Germany seeks to achieve eight goals ${ }^{72}:$ 1) Peace and security; 2) Diversifying and deepening relations; 3) Neither unipolar nor bipolar; 4) Open shipping routes; 5) Open markets and free trades; 6) Digital transformation and connectivity; 7) Protecting our planet; 8) Access to fact-based information. Germany relies on seven principles that guide its strategy in the

${ }^{68}$ Federal Foreign Office, Germany, "Germany-Europe-Asia: shaping the 21st century together": The German Government adopts policy guidelines on the Indo-Pacific region, 2020, September 1, https://www.auswaertiges-amt.de/en/aussenpolitik/regionaleschwerpunkte/asien/german-government-policy-guidelines-indo-pacific/2380510

${ }^{69}$ Frederic Grare, "Germany's New Approach to the Indo-Pacific, Carnegie Endowment for International Peace", Carnegie Endowment for International Peace, Internationale Politik Quarterly, 2020, October 15:1, https://carnegieendowment.org/2020/10/15/germany-s-newapproach-to-indo-pacific-pub-82978

${ }^{70}$ Federal Foreign Office, Germany, "Germany-Europe-Asia: shaping the 21st century together": The German Government adopts policy guidelines on the Indo-Pacific region.

71 Ibidem, 5.

72 Ibidem, 9-10. 
Indo-Pacific to achieve these goals $\left.{ }^{73}: 1\right)$ Promote coordinated European action (based on the EU Global Strategy 2016); 2) Bet on multilateralism by strengthening economic, political, and security ties with Indo-Pacific nations; 3) Support an Indo-Pacific based on rules-based order; 4) Incorporate the 17 Sustainable Development Goals (SDG) of the United Nations to the actions carried out in the Indo-Pacific; 5) Defend Human Rights; 6) Promote the inclusiveness of all nations involved in the Indo-Pacific to strengthen peace, security, and stability in the region; 7) Promote partnerships between equals with Indo-Pacific nations in third countries to share global responsibilities.

\section{IV.III. The economic dimension and Netherlands}

Finally, the Netherlands has been the third European nation to offer a national strategy for the Indo-Pacific in November 2020, also offering the shortest document (10 pages) and published only in Dutch at the source. In it, the Netherlands, like Germany, articulates its strategy based on eight dimensions of strategic interest ${ }^{74}$ : the defense of the international legal order, the promotion of democracy and human rights, security and stability, sustainable trade, safe passage, and maritime security, address the climate change, global healthcare and poverty reduction.

The Netherlands also highlights the integration of its strategy into coordinated action within the EU by stating ${ }^{75}$,

"The Netherlands would like to see the EU develop its own vision of the Indo-Pacific, aimed at promoting EU cooperation with the region on the basis of a distinctive EU agenda so as to protect and promote our own interests. At the same time, the Netherlands must consider how it can contribute itself to an EU agenda by strengthening its bilateral ties with the countries of the Indo-Pacific".

On the strategic alliances that the Netherlands advocates, the document states that they should prioritize like-minded nations such as Australia, Japan, New Zealand, South Korea, and India, as well as strategic colla-

73 Ibidem, 11-12.

${ }^{74}$ Government of the Netherlands, Netherlands, Indo-Pacific: Guidelines for strengthening Dutch and EU cooperation with partners in Asia, 2020, https://www.government. nl/binaries/government/documents/publications/2020/11/13/indo-pacific-guidelines/IndoPacific+Guidelines+EN.pdf

75 Government of the Netherlands, Netherlands, Indo-Pacific: Guidelines for strengthening Dutch and EU cooperation with partners in Asia. 
borations with ASEAN. Without explicitly mentioning China, the Netherlands is making its position on building a security architecture in the Indo-Pacific clear.

\section{IV.IV. The EU's geopolitical strategy for the Indo-Pacific}

Finally, the European External Action Service (EEAS) of the European Union announced in March 2021 the need to develop a strategic European position on the Indo-Pacific ${ }^{76}$, filling a hole in its global projection that contrasted with the assertiveness of other actors with whom it shares close political and strategic ties such as the US, Japan, India, and Australia. This commitment was materialized by the EU's High Representative of the European Union for Foreign Affairs and Security Policy and Vice-President of the European Commission, Josep Borrell, announcing ${ }^{77}$ : "From trade and investment, to connectivity, climate action and security, we have a big stake in the Indo-Pacific and should do our part to keep the regional order open and rules-based". This declaration heralded the end of a long strategic absence in the EU taking an international position on the Indo-Pacific.

It has been suggested that one of the reasons for this European parsimony is China's economic dent made in the heart of the EU ${ }^{78}$ through its Belt and Road Initiative (BRI) ${ }^{79}$. The so-called "checkbook diplomacy", a term used to refer to the Chinese BRI, could have been the main impediment to the fruition of serious community interest in developing some type of strategy in the region that could upset the Asian giant. Therefore, it is not surprising that the nations most critical of how China has landed in Europe, such as France and Germany, have also been the first to have developed their own national strategy. It must also be mentioned that, even though the European (and other) nations backing the FOIP take special care

${ }^{76}$ European External Action Service (EEAS), The EU needs a strategic approach for the Indo-Pacific, 2020, March 12. https://eeas.europa.eu/headquarters/headquarters-homepage/94898/eu-needs-strategic-approach-indo-pacific_en, Accessed August 1, 2021

77 European External Action Service (EEAS), The EU needs a strategic approach for the Indo-Pacific.

${ }^{78}$ Feliz Heiduk \& Nedim Sulejmanovic, "Will the EU take view of the Indo-Pacific? Comparing France's and Germany's approaches", Working Paper 1, German Institute for International and Security Affairs, 2021, January, https://www.swp-berlin.org/fileadmin/ contents/products/arbeitspapiere/WP_EU_Indopacific_Heiduk_Sulejmanovic.pdf

79 Eva Pejsova, "The Indo-PacificA passage to Europe?", BRIEF 3, Connectivity \& Security Along the Road, EUISS - Series, European Institute for Security Studies (EUISS), 2018, March, https://www.iss.europa.eu/sites/default/files/EUISSFiles/Brief\%203\%20 The\%20Indo-Pacific_0.pdf, Accessed August 1, 2021. 
not to officially present this initiative as a rival, threat, or alternative to the BRI, the geopolitical implications of these both models are clear.

Therefore, if one were to accept the view that the European Union is torn between a more pro-BRI stance and a more pro-Indo-Pacific one, one would find a clear disruptive line of an economic nature at the heart of the EU. The richest nations - France, Germany, and the Netherlands - have taken a pro-Indo-Pacific stance. The poorest nations (especially the ones in southern Europe still recovering from the 2008 crisis) have adopted a more pro-BRI stance). Therefore, the "checkbook diplomacy" plays a fundamental role not only in the geopolitical projection of European nations but also on the question of European cohesion and in its capacity to geopolitically coordinate itself.

This radical break in geopolitical terms within the EU itself represents a serious obstacle not only for European projection in the Indo-Pacific, but also for reaching future strategic agreements between European member partners. The commitments made with China may prevent the European nations that have signed them from supporting or giving approval to more assertive European positions regarding the Asian giant on human rights, state interventionism in markets with European participation, Chinese military expansionism at sea, or China's treatment of ethnic minorities (such as the Uighurs) or political assertiveness (such as in Hong Kong).

These implications can also extend to other international areas that would be vital for the EU. An example of this would be the opening of the first Chinese military base abroad in Djibouti, which would allow China to project its military force in the Gulf of Aden, a vital geostrategic point through which is an important part of the supply of crude oil, products, and raw materials from the EU. Likewise, this could compromise the European position on the trade war between the US and China, the EU position on the clashes between China and Japan in the Senkaku / Diaoyu Islands, and the role of Europe in redefining a new balance of powers in a multipolar world.

For this reason, the European geopolitical division not only damages Europe's role in this area of the planet but also compromises the EU's own ability to operate in the future as a coordinated entity with one voice. This situation can be solved with the announced future EU strategy regarding the Indo-Pacific, allowing the EU not only to project its voice in this region of the planet, collaborating with democracies and free-market economies but also to consolidate itself internally as a more cohesive actor when making strategic decisions. 


\section{Conclusions}

The Indo-Pacific is becoming the new geopolitical axis of the planet, which is a reason for Europe to abandon its long strategic absence in the region and develop its own strategies for it. This has been reflected in the development of the three national strategies to date, as well as in the announcement of future development of a European strategy. The three nations that have developed their own national strategies have been France in 2019 (focusing on security), Germany in 2020 (focusing on multilateralism), and the Netherlands also in 2020 (focusing on trade). These three strategies reveal the triple importance that the region has for the world in general and Europe in particular: security (with six recognized nuclear powers including France), economic (with 62 percent of world Gross Domestic Product (GDP), and demographic (with the 64 percent of the world's population).

In March 2021 the future development of an EU strategic document for the Indo-Pacific was announced, ending a European absence and marking a turning point in the global projection of the European Union. This paradigm shift may mark a change in relations of the EU with China since the commitment to a European strategy in the Indo-Pacific would imply a displacement of the weight that China can play both in the region and in the relationship with the EU. The impact of COVID-19 may have accelerated this process by disrupting the global supply chain and, thus, reducing the European trade dependence with China, at least temporarily. It will take time to see if this historic event is accompanied by a greater European presence in the Indo-Pacific. In any case, although the guidelines in the EU document are still generic, it may mark the beginning of greater European cohesion and assertiveness not only in the Indo-Pacific but in many other geopolitical scenarios.

\section{Sobre el autor}

Juan Luis López-Aranguren es Profesor Doctor de Derecho Internacional Público y Relaciones Internacionales en la Facultad de Derecho de la Universidad de Zaragoza, así como en el Máster Universitario de la Abogacía. Es asimismo miembro del Grupo de Investigación Japón y profesor de la asignatura de Investigación en Estudios Japoneses en el Máster en Estudios Japoneses de la misma universidad. Ha sido investigador postdoctoral de la Japan Foundation en la Universidad de Osaka y en la Internacional University of Japan (IUJ) como IP de su investigación sobre la relación entre comunicación internacional y cohesión social japonesa. Completó su 
doctorado internacional sobre la aplicación de la teoría de la elección racional en las relaciones internacionales, estudiando el conflicto de las islas Senkaku/Diaoyu entre Japón y China. Ha sido investigador visitante en universidades de Reino Unido, Japón, India, Tailandia y Nueva Zelanda.

\section{About the author}

Juan Luis López-Aranguren is a Ph.D. Professor of Public International Law and International Relations at the Faculty of Law of the University of Zaragoza, as well as in the Máster Universitario de la Abogacía. He is also a member of the Japan Research Group and also teaches the Master's degree paper "Research on Japanese Studies" at the same university. He has been a postdoctoral researcher at the Japan Foundation at Osaka University and the International University of Japan (IUJ) as Principal Investigator for his research on the relationship between international communication and Japanese social cohesion. He completed his international $\mathrm{Ph} . \mathrm{D}$. on the application of rational choice theory in international relations, studying the Senkaku / Diaoyu Islands conflict between Japan and China. Has been a visiting researcher at universities in the UK, Japan, India, Thailand, and New Zealand. 


\section{Derechos de autor}

Los derechos de autor (para la distribución, comunicación pública, reproducción e inclusión en bases de datos de indexación y repositorios institucionales) de esta publicación (Cuadernos Europeos de Deusto, CED) pertenecen a la editorial Universidad de Deusto. El acceso al contenido digital de cualquier número de Cuadernos Europeos de Deusto es gratuito inmediatamente después de su publicación. Los trabajos podrán leerse, descargarse, copiar y difundir en cualquier medio sin fines comerciales y según lo previsto por la ley; sin la previa autorización de la Editorial (Universidad de Deusto) o el autor. Así mismo, los trabajos editados en CED pueden ser publicados con posterioridad en otros medios o revistas, siempre que el autor indique con claridad y en la primera nota a pie de página que el trabajo se publicó por primera vez en CED, con indicación del número, año, páginas y DOI (si procede). Cualquier otro uso de su contenido en cualquier medio o formato, ahora conocido o desarrollado en el futuro, requiere el permiso previo por escrito del titular de los derechos de autor.

\section{Copyright}

Copyright (for distribution, public communication, reproduction and inclusion in indexation databases and institutional repositories) of this publication (Cuadernos Europeos de Deusto, CED) belongs to the publisher University of Deusto. Access to the digital content of any Issue of Cuadernos Europeos de Deusto is free upon its publication. The content can be read, downloaded, copied, and distributed freely in any medium only for non-commercial purposes and in accordance with any applicable copyright legislation, without prior permission from the copyright holder (University of Deusto) or the author. Thus, the content of CED can be subsequently published in other media or journals, as long as the author clearly indicates in the first footnote that the work was published in CED for the first time, indicating the Issue number, year, pages, and DOI (if applicable). Any other use of its content in any medium or format, now known or developed in the future, requires prior written permission of the copyright holder. 